\author{
A.K. Zeinidenov, N.Kh. Ibrayev \\ Ye.A. Buketov Karaganda State University, Kazakhstan \\ (E-mail: a.k.zeinidenov@gmail.com)
}

\title{
Photovoltaic and electrophysical properties of plasmon-enhanced organic solar cells
}

\begin{abstract}
A technique for depositing plasmon silver nanoparticles into various functional layers of an organic solar cell has been developed. Analysis of the structure of nanoparticles was carried out according to electron microscopic images on an electron microscope MIRA 3 LMU, Tescan. Electron microscopic analysis showed the presence of spherical silver nanoparticles. The size of silver nanoparticles was $\sim 100-200 \mathrm{~nm}$. The frequency of plasmon resonance lies in the region of 451-457 $\mathrm{nm}$. The microstructural and optical properties of nanocomposite materials obtained are studied. The film thickness of the deposited photoactive layer P3HT: PCBM is $229 \mathrm{~nm}$, the thickness of the deposited silver film is $87 \mathrm{~nm}$, respectively. It is shown that the absorption band of silver nanoparticles on the ITO surface has a maximum at the wavelength of $457 \mathrm{~nm}$. For silver nanoparticles on the P3HT / PCBM surface, the maximum wavelength is shifted to the shortwave region at $451 \mathrm{~nm}$. The photovoltaic and electrotransport properties of film polymer compositions based on P3NT: RSVM and silver nanoparticles are studied.Measurement of the volt-ampere characteristic of the cells was carried out by illuminating the cell from the side of the conducting layer of the ITO. It is shown that the deposition of silver nanoparticles on the ITO surface increases the PSC efficiency by 1.7 times. When the film of silver nanoparticles is positioned between PEDOT / PSS and the photoactive layer of P3HT / PCBM, the efficiency is reduced by approximately 1.8 times. In the presence of silver nanoparticles, a further reduction in the cell efficiency is observed on the surface of the P3HT / PCBM photoactive layer. Doping of silver nanoparticles into the photoactive layer of P3HT / PCBM also leads to a decrease in the cell efficiency. The electron transport properties of a solar cell with a bulk heterojunction were studied using the method of electrochemical impedance spectroscopy (EIS). It is shown that a significant increase in the cell efficiency is observed when silver nanoparticles are deposited on the ITO surface. Precipitation of silver nanoparticles on the surface of the PEDOT:PSS layer and doping them into the P3HT: PCBM volume reduces the conversion of solar energy into electrical energy.
\end{abstract}

Keywords: Silver, plasmon resonance, organic solar cells, poly(3-hexylthiophene), films.

\section{Introduction}

In recent years the increasing interest in nanocomposite materials on the basis of organic semiconductor polymers and metal nanoparticles (NPs) is noted. Interest in these materials is connected with their unique optical properties, caused by the phenomenon of the superficial plasmon resonance (SPR) which is shown in emergence of an intensive strip of absorption in visible area of a range [1,2]. A research of such nanocomposites are important both the problem in understanding of mechanisms, and ample opportunities of use of processes of the superficial plasmon resonance (SPR) in development of new materials for effective optoelectronic and the photovoltaic of devices $[3,4]$.

For increase in overall performance of organic solar cells new semiconductor polymers are synthesized now or excitement of plasmons on a surface of metal NPs is used. So in work [5, 6] plasmon silver NPs in various layers of organic solar cells on the basis of a volume heterojunction of the P3HT:PCBM system were used. It is shown that, the best value of efficiency of organic solar cells is received when using NPs of silver in direct contact with an active layer. Thus, in connection with increase in efficiency of organic solar cells with a volume heterojunction, becomes more and more important to investigate hybrid photo cells on a basis the plasmon of metal NPs.

In the real work results of a research of influence of nanoparticles of silver, the doping are presented to various functional layers, to current-voltage characteristics (VAC) and electrophysical properties of organic solar cells with a volume bulk heterojunction organic solar cells.

\section{Experimental}

For assembly of solar cells as a substrate glasses $(2 \times 2 \mathrm{~cm})$ on a half the covered ITO with the surface resistance of 10-15 Ohms $/ \mathrm{cm}^{2}$ which serves as the top electrode were used. In the course of cleaning of a substrate upright were located in UF a bathtub and sequentially $10 \mathrm{~min}$. were washed out in an acetone, in isopropyl alcohol and in the deionized water, later were dried up by a nitrogen stream. At the end for remov- 
al of oddments of organic chemistry from a surface and increase in wettability, they were exposed UF-ozon to processing within 1 hour. PEDOT:PSS was applied on the cleared substrates with method of a centrifugation (spin-coating). For receiving a qualitative film of PEDOT:PSS, 50 an aqueous solution of PEDOT:PSS (Ossila) it was dripped on the substrate surface placed on the centrifuge, further a substrate it was untwisted with acceleration $500 \mathrm{rpm} / \mathrm{sec}^{2}$ to the speed of $2000 \mathrm{rpm}$ and maintained within $2 \mathrm{~min}$. Later, from a substrate by means of a watt stick was removed a small part of a film from ITO (the cell anode).

At the end the substrate with the put film was located in glove isolation ward with nitrogen and was annealed at a temperature of $150{ }^{\circ} \mathrm{C}$ within $5 \mathrm{~min}$. for improvement of structure of a film and electro transport properties. The photo fissile layer of P3HT:PC60BM was also put with a centrifugation. For receiving efficient cells the photo fissile layer was put according to the following technique: $20 \mathrm{mg}$ of the mix P3HT:PC60BM in the ratio of 1:1 (Sigma-Aldrich) were dissolved in $1 \mathrm{ml}$ of benzene chloride (SigmaAldrich), solution was maintained at a temperature of $45{ }^{\circ} \mathrm{C}$ at intensive hashing on a magnetic stirrer with heating not less than 24 clocks. After that solution was filtered by 0,45 micrometer filter. The prepared solution in number of $25 \mathrm{mcL}$ was applied on the substrate rotating with a speed of $2000 \mathrm{rpm}$ and maintained at this speed more than $20 \mathrm{sec}$. for the complete evaporation of solvent. Then, it is similar with drawing PEDOT:PSS, from ITO was removed a small part of a film. The aluminum electrode 120 nanometers thick was put with a thermal dusting. The film of silver $60 \mathrm{~nm}$ thick was put with a thermal dusting in vacuo on the installation which is built in glove isolation ward. For receiving films of silver shots of $\mathrm{AgNO}_{3}$ weighing $3 \mathrm{mg}$ were prepared. The dusting was made in vacuo $\sim 10^{-5} \mathrm{Pas}$ with a speed of $0,5 \mathrm{~nm} / \mathrm{sec}$.

At the last stage of a substrate were tempered in a nitrogen atmosphere at a temperature $150{ }^{\circ} \mathrm{C}$ within 15 min. for improvement of a crystalline of P3HT and quality of a film in general. After preparation all exemplars were stored in a glove box for an exception of uncontrollable degradation of exemplars. The design of an organic solar cell with silver nanoparticles, the doping in various functional layers, is presented in the Figure 1.

a)

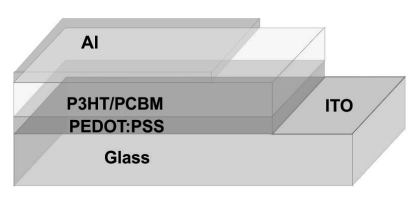

c)

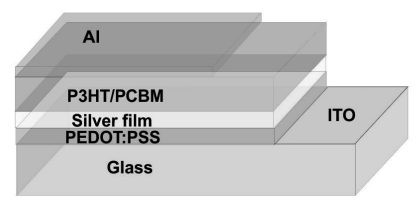

b)

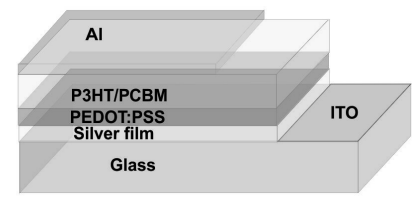

d)

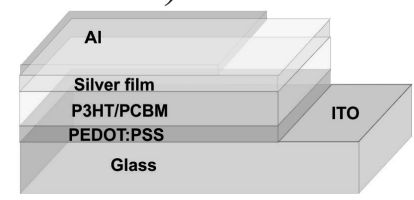

Figure 1. A design of an organic solar cell with silver nanoparticles doping in various functional layers

Current voltage characteristics of cells measured at radiation by light with a range the close to AM1.5 $\left(100 \mathrm{MW} / \mathrm{cm}^{2}\right)$ with use of the solar simulator Photo Emission Tech Inc Solar Cell IV Measurement. Intensity of a luminous flux was controlled by means of the calibrated silicon diode with the known spectral characteristic. For record of volt-ampere curves used Keithley 2400 source meter. Accuracy of filing of tension of a no-load operation made $\pm 50 \mathrm{mkV}$, short-circuit current $\pm 10 \mathrm{pA}$. Accuracy of gravity test of current of a short-circuit was defined by biases of the area of the device which did not exceed $3 \%$.

\section{Results and discussion}

Determination of thickness of the put layer was carried out by means of the scanning super microscope of MIRA 3 LMU, Tescan. The chip of glass was investigated with use of the detectors SE (the detector of secondary electrons) and BSE (the detector of the reflected electrons) at the accelerating voltage of $20 \mathrm{kV}$. From the Figure 2 it is visible that thickness of a film of the put photo fissile layer of P3HT:PCBM makes $229 \mathrm{~nm}$, thickness of the besieged film of silver makes $87 \mathrm{~nm}$ respectively. 


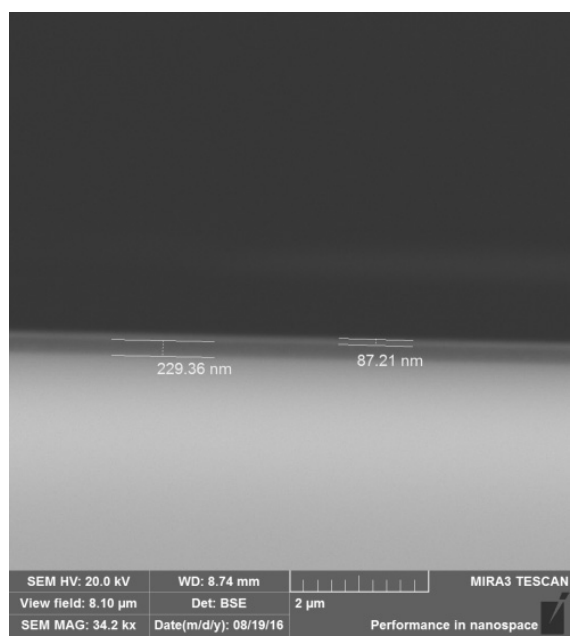

Figure 2. SEM of the image of films of silver on a surface the photo fissile layer of P3HT:PCBM

In the Figure 3 SEM of the image of the silver NPs besieged on a surface of ITO and the photo fissile layer of P3HT:PCBM are presented.

From the drawing it is visible that, at a deposition of silver NPs on a surface of ITO (a) mainly spherical particles are formed. At a deposition of silver NPs on a surface of the photo fissile layer of P3HT:PCBM particles of both spherical shape, and oblong shape are observed. Change of the NPs form of silver, probably, is bound to the fact that at final assembly of PSC their annealing in a nitrogen atmosphere at a temperature is made $150{ }^{\circ} \mathrm{C}$. On the basis of the obtained electronic and microscopic data it is established that average particle size of silver makes $\sim 80-110$ nanometers.

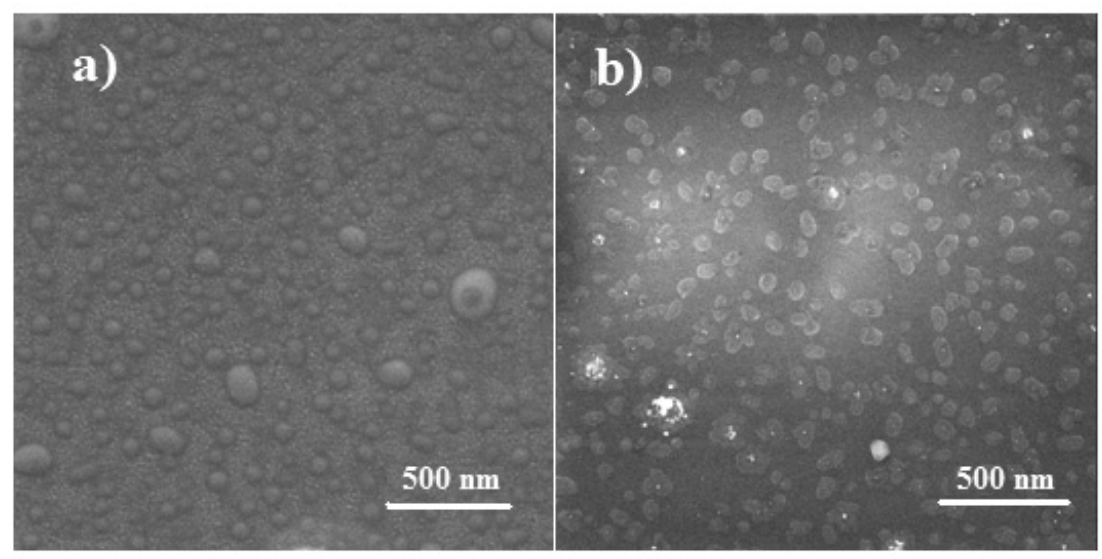

Figure 3. SEM the image of nanoparticles of silver on a surface ITO $(a)$ and the photo fissile layer of P3HT:PCBM $(b)$

In the Figure 4 optical spectrums of absorption the plasmon of silver NPs are shown. Apparently from the drawing (a curve 1) the absorption band of silver NPs on a surface of ITO has a maximum on a wavelength of $\lambda_{1}^{\max }=457 \mathrm{~nm}$ and half-width $\Delta \lambda_{\frac{1}{2}}^{a b s}=217 \mathrm{~nm}$. For silver NPs (a curve 2) on P3HT/PCBM surface at most of a wavelength it is displaced to the short-wave area of $\lambda_{1}^{\max }=451 \mathrm{~nm}$. Observed shifts of a maximum of a plasmon resonance to the short-wave area, it is bound to change of the form of silver NPs (Fig. 3b). 


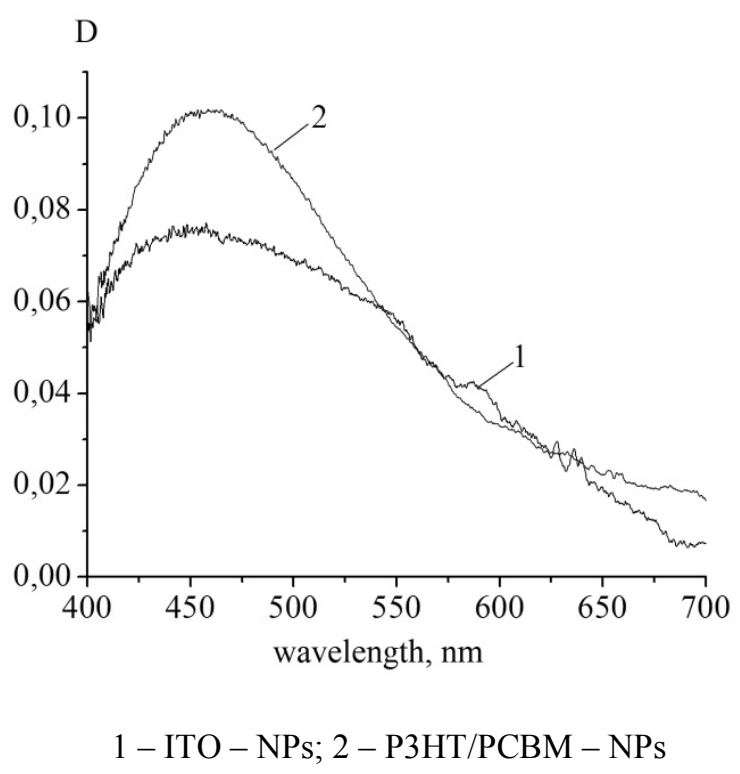

Figure 4. Absorption spectra plasmon of silver NPs in various functional layers of PSC

\section{$\mathrm{I}, \mathrm{mA} / \mathrm{cm}^{2}$}

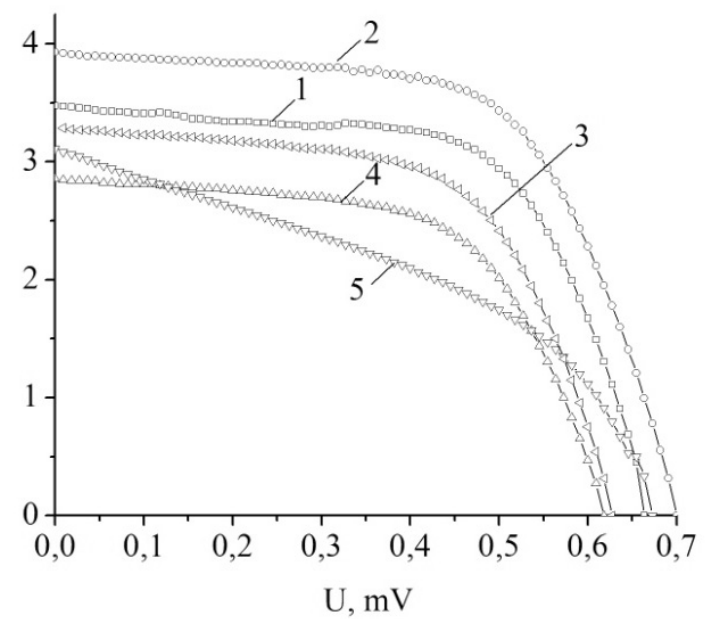

Figure 5. VAC of organic solar cells with the introduced of silver

In the Figure 5 are shown VAC of organic solar cells with NPs of Ag besieged in various functional layers of a cell. Measurement VAC of cells was taken at illumination of a cell from a conducting stratum of ITO. From the presented curves VAKH it is visible that at a deposition (a curve 2) the efficiency of PSC increases by a surface of ITO of silver NPs by 1,7 times. At an arrangement of a film of silver NPs between PEDOT/PSS and the photo fissile layer of P3HT/PCBM (a curve 4) decrease in efficiency, approximately, by 1,8 times is observed. In the presence of NPs of silver on a surface of the photo fissile layer of $\mathrm{P} 3 \mathrm{HT} / \mathrm{PCBM}$ (a curve 5) further decrease in efficiency of a cell is observed. Doping silver NPs in the photo fissile layer of P3HT/PCBM (a curve 3), also leads to decrease in efficiency of a cell. The main characteristics of polymeric solar cells with NPs of silver in various functional layers are presented in Table 1.

$\mathrm{Tab}$ e 1

\section{Characteristics of organic solar cells in the presence of silver NPs}

\begin{tabular}{|l|c|c|c|c|c|c|}
\hline \multicolumn{1}{|c|}{ Example } & $\begin{array}{c}U_{x,} \\
m V\end{array}$ & $\begin{array}{c}I_{k^{3},} \\
m A\end{array}$ & $\begin{array}{c}U_{\max } \\
m V\end{array}$ & $\begin{array}{c}I_{\max } \\
m A\end{array}$ & $F F$ & $\eta, \%$ \\
\hline Without NPs & 0,66 & 1,10 & 0,49 & 0,90 & 0,63 & 1,46 \\
\hline ITO - NPs & 0,70 & 1,78 & 0,50 & 1,30 & 0,56 & 2,10 \\
\hline $\begin{array}{l}\text { NPs doped in } \\
\text { P3HT/PCBM }\end{array}$ & 0,60 & 0,94 & 0,35 & 0,90 & 0,55 & 1,10 \\
\hline $\begin{array}{l}\text { PEDOT/PSS - } \\
\text { NPs }\end{array}$ & 0,62 & 0,90 & 0,30 & 0,70 & 0,55 & 0,84 \\
\hline $\begin{array}{l}\text { P3HT/PCBM } \\
- \text { NPs }\end{array}$ & 0,67 & 0,92 & 0,20 & 0,45 & 0,52 & 0,36 \\
\hline
\end{tabular}

Electron-transport properties of a solar cell with a volume heterojuction were investigated by means of a method of an electrochemical impedance spectroscopy (EIS). Measurements were taken by EIS under the reference feigned sunlight of AM 1.5, 100 of $\mathrm{mV} / \mathrm{cm}^{2}$ (PET PHOTO Emission TECH., INC.) on an impedansometry Z-500PRO (Elins), amplitude and range of frequency of the enclosed sine signal $-10 \mathrm{mV}$ and $100 \mathrm{kHz}-100 \mathrm{MHz}$, respectively. In the Figure 6 impedance hodographs in Nyquist's coordinates for organic solar cells with a volume heterojunction are shown. 


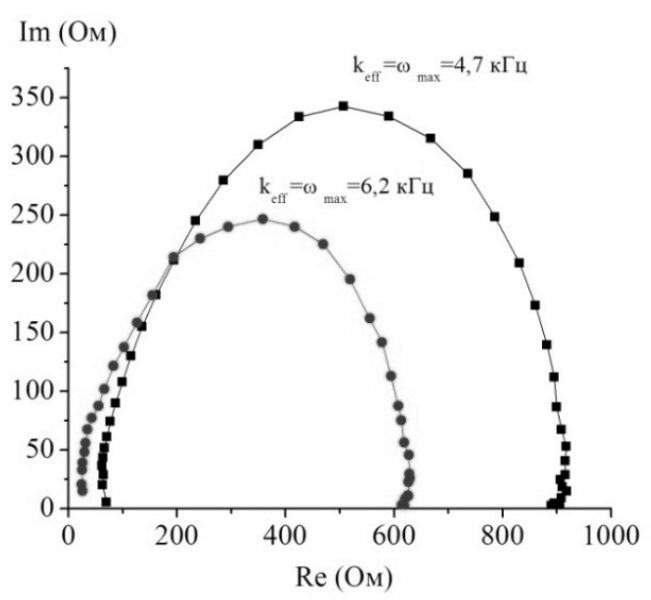

Figure 6. Ranges of an impedance of organic solar cells

From the submitted data it is visible that the range of an impedance consists from several circles. By the technique described in $[7,8]$ from the central arch of ranges of an impedance the efficient diffusion coefficient of electrons of $D_{\text {eff; }}$, an efficient recombination rate of $k_{\text {eff, }}$ an efficient lifetime of an electron $\tau_{\text {eff, }}$, resistance to electronic transport in a film of dioxide of a titanium $R_{w}$, resistance of charge transfer of $R_{k}$, the bound to an electron recombination were calculated. For solar cells with doping nanoparticles of silver in layers of PEDOT/PSS- NPs and P3HT/PCBM - NPs ranges of an impedance were not registered. It demonstrates that cells have low overall performance. The received results are presented in Table 2.

\section{Electrotransport parameters of organic solar cells}

\begin{tabular}{|l|c|c|c|c|c|}
\hline Annealing temperature & $D_{\text {eff }}$ & $\begin{array}{c}k_{\text {eff }} \\
\left(c^{-1}\right)\end{array}$ & $\begin{array}{c}\tau_{\text {eff }} \\
(c)\end{array}$ & $\begin{array}{c}R_{k} \\
(O M)\end{array}$ & $\begin{array}{c}R_{w} \\
(O M)\end{array}$ \\
\hline Without NPs & $9.9^{*} 10^{-5}$ & 4714 & 0,0002 & 850 & 69 \\
\hline ITO - NPs & $4.7^{*} 10^{-5}$ & 6250 & 0,00016 & 600 & 26 \\
\hline
\end{tabular}

From Table 2 data it is visible that resistance to electronic transport in solar cells in lack of silver NPs $(\mathrm{Rw})$ is higher, than in solar cells with silver NPs. Thus, the significant increase in efficiency is observed at a solar cell in which contains silver nanoparticles in ITO- NPs layers, a doping of nanoparticles of silver in the functional the layer of PEDOT/PSS and P3HT/PCBM leads transformation of solar energy to electric to decrease. The reasons of changes VAC in films of PEDOT/PSS-NPs and P3HT/PCBM - NPs are not established and demand carrying out further researches.

\section{References}

1 Maier S.A. Plasmonics: Fundamentals and Applications. — Berlin: Springer, 2007.

2 Margueritat J. Surface Plasmons and Vibrations of Self-Assembled Silver Nanocolumns / J. Margueritat, J. Gonzalo, C.N. Afonso, A. Mlayah, D.B. Murray, L. Saviot// Nano Lett. — 2006. - Vol. 6. - P. 2037-2042.

3 Gao H. Direct Evidence for Surface Plasmon-Mediated Enhanced Light Transmission through Metallic Nanohole Arrays / H. Gao, J. Henzie, T.W. Odom // Nano Lett. - 2006. - Vol. 6. - P. 2104-2108.

4 Mihalcea C. Improving the efficiency and reducing efficiency roll-off in quantum dot light emitting devices by utilizing plasmonic Au nanoparticles / C. Mihalcea, D. Buchel, N. Atoba, J. Tominaga. — J. Mater. Chem. 2013. — Vol. 1. — P. $470-476$.

5 Kalfagiannis N. Plasmonic silver nanoparticles for improved organic solar cells / N. Kalfagiannis, P.G. Karagiannidis, C. Pitsalidis, N.T. Panagiotopoulos, C. Gravalidis, S. Kassavetis, P. Patsalas, S. Logothetidis. - Solar Energy Materials \& Solar Cells. - 2012. - Vol. 104. - P. 165-174.

6 Zeinidenov A.K. Structural properties and photoinduced electron processes in polymer films of poly(3-hexylthiophene-2,5diyl) on the surface of silver island films. The 6th International conference «Nanomaterials: Applications and Properties» (14-19 September) / A.K. Zeinidenov, N.Kh. Ibrayev, D.A. Afanasyev. - 2016. - P. 1-2.

7 Fabregat-Santiago F. Influence of electrolyte in transport and recombination in dye-sensitized solar cells studied by impedance spectroscopy / F. Fabregat-Santiago, J. Bisquert, G. Garcia-Belmonte. - Solar Energy Materials \& Solar Cells, 2005. Vol. 87. - P. 117-131.

8 Adachi M. Determination of Parameters of Electron Transport in Dye-Sensitized Solar Cells Using Electrochemical Impedance Spectroscopy / M. Adachi, M. Sakamoto, J. Jiu. - J. Phys. Chem. B, 2006. — Vol. 110. — P. 13872-13880. 


\title{
А.К. Зейниденов, Н.Х. Ибраев \\ Плазмон-күшейтілген органикалық күн ұяшықтарының фотовольтаикалық және электрфизикалық қасиеттері
}

\begin{abstract}
Органикалық күн ұяшығының әртүрлі функционалды қабатында плазмонды күміс нанобөлшегінің тұндыру әдісі жасалынды. Нанобөлшектің құрылымына талдау MIRA 3 LMU, Tescan электронды микроскопында түсірілген электронды-микроскопиялық түсірілімдерінің берілгендері бойынша жүзеге асырылды. Электронды-микроскопиялық талдауда күміс нанобөлшегінің бар екенін көрсетті. Күміс нанобөлшегінің өлшемі 100-200 нм құрады. Плазмондық резонанс жиілігі 451-457 нм облысында жатыр. Алынған нанокомпозитті материалдардың оптикалық және микроқұрылымдық қасиеттері зерттелді. РЗНТ:РСВМ фотобелсенді қабаты жағылған қабыршақ қалыңдығы 229 нм құрайды, күмістің тұндырылған қабыршағының қалыңдығы сәйкесінше 87 нм-ге тең. ITO бетіндегі күміс нанобөлшегінің жұтылу жолағы нм толқын ұзындығында максимумға ие екені көрсетілді. P3НT/РCВМ бетіндегі күміс нанобөлшегі үшін толқын ұзындығының максимумы 451 нм қысқа толқынды облысқа жылжиды. Күміс нанобөлшегінің және Р3НТ:РСВМ негізінде қабыршақты полимерлі кешендерінің электртранспорттық және фотовольтаикалық қасиеттері зерттелді. ITO өткізетін қабатының жағынан ұяшқты жарықтандырған кезде ұяшықтың вольтамперлік сипаттамасы жүргізілді. ITO бетіне күміс нанобөлшегін қондырған кезде ПЭК PSC 1,7 рет үлкейгені көрсетілді. PEDOT/PSS және P3HT/PCBM фотобелсенді қабаты арасына күміс нанобөлшегін орналастырған кезде ПӘК төмендегені байқалады, шамамен 1,8 рет. Бетінде күміс нанобөлшегі бар Р3НТ/РСВМ фотобелсенді қабаты ұяшықтың ПӘК төмендеуіне әкелетінін байқалды. Күміс нанобөлшегі енгізілген P3НТ/РCВМ фотобелсенді қабаты ұяшықтың ПӘК төмендеуіне әкелді. Көлемді гетероөтулермен күн ұяшығының электрон-транспорттық қасиеті электрохимиялық импендансты спектроскопия (EIS) әдісінің көмегімен зерттелді. Ұяшықтың ПӘК айтарлықтай өсуі күміс нанобөлшегін ITO бетіне тұндыру кезінде байқалатыны көрсетілді. PEDOT:PSS беткі қабатына және P3HT:PCBM көлеміне енгізілген күміс нанобөлшегінің тұнбасы күн энергиясын электрлікке түрлендірудің төмендеуіне әкелді.
\end{abstract}

Кілт сөздер: күміс, плазмондық резонанс, органикалық күн ұяшықтары, poly(3-hexylthiophene), қабықша.

\section{А.К. Зейниденов, Н.Х. Ибраев \\ Фотовольтаические и электрофизические свойства плазмон-усиленных органических солнечных ячеек}

\begin{abstract}
Разработана методика осаждения плазмонных наночастиц серебра в различные функциональные слои органической солнечной ячейки. Анализ структуры наночастиц осуществлялся по данным электронно-микроскопических снимков на электронном микроскопе MIRA 3 LMU, Tescan. Электронномикроскопический анализ показал наличие сферических НЧ серебра. Размер НЧ серебра составил 100-200 нм. Частота плазмонного резонанса лежит в области 451-457 нм. Исследованы микроструктурные и оптические свойства полученных нанокомпозитных материалов. Толщина пленки нанесенного фотоактивного слоя РЗНТ:РСВМ составляет 229 нм, толщина осажденной пленки серебра 87 нм. Показано, что полоса поглощения НЧ серебра на поверхности ITО имеет максимум на длине волны 457 нм. Для НЧ серебра на поверхности Р3НТ/РСВМ максимум длины волны смещается в коротковолновую область на 451 нм. Исследованы фотовольтаические и электротранспортные свойства пленочных полимерных композиций на основе Р3НТ:РСВМ и наночастиц серебра. Измерение ВАХ ячеек проводилось при освещении ячейки со стороны проводящего слоя ITO. Показано, что при осаждении на поверхность ITO НЧ серебра КПД РSC увеличивается в 1,7 раза. При расположении пленки НЧ серебра между PEDOT/PSS и фотоактивным слоем Р3НT/РСВМ наблюдается понижение КПД примерно в 1,8 раза. В присутствии НЧ серебра на поверхности фотоактивного слоя Р3НТ/РСВМ наблюдается дальнейшее понижение КПД ячейки. Допирование НЧ серебра в фотоактивный слой Р3НТ/РСВМ также приводит к понижению КПД ячейки. Электрон-транспортные свойства солнечной ячейки с объемным гетеропереходом исследовались с помощью метода электрохимической импедансной спектроскопии (EIS). Показано, что значительное увеличение КПД ячейки наблюдается при осаждении наночастиц серебра на поверхность ITO. Осаждение наночастиц серебра на поверхность слоя PEDOT:PSS и допирование их в объем Р3НT:PCBM приводят к уменьшению преобразования солнечной энергии в электрическую.
\end{abstract}

Ключевые слова: серебро, плазмонный резонанс, органические солнечные ячейки, поли(3-гексилтиофен), пленки. 